\title{
Carbohydrates on the growth of Cattleya schilleriana Reichb.f. seedlings (Orchidaceae)
}

\author{
Renato Fernandes Galdiano Júnior ${ }^{1^{*}}$ - Cibele Mantovani $^{1}$ \\ Eliana Gertrudes de Macedo Lemos ${ }^{1}$
}

${ }^{1}$ Faculdade de Ciências Agrárias e Veterinárias, Universidade Estadual Paulista “Júlio de Mesquita Filho" (UNESP), Via de Acesso Prof. Dr. Paulo Donato Castellane, S/No , Zona Rural, 14884-900, Jaboticabal, SP, Brasil. E-mail: renatofgaldianojr@yahoo.com.br. ${ }^{*}$ Corresponding author.

\begin{abstract}
The aim of the present study was to evaluate the effects of carbohydrate supplementation on the propagation of the orchid Cattleya schilleriana. The 120-d-old seedlings were subcultured in fructose-, glucose-, or sucrose-supplemented (0, 15, 30, and 45g L-1) 1/2 MS culture medium (half-strength macronutrient concentrations), using a completely random design with four repetitions per treatment. After 120d of treatment, root number and length, leaf number and length, and fresh weight were evaluated, and seedling survival was evaluated after $75 d$ of acclimatization in a greenhouse. The in vitro growth data were submitted to regression analysis, whereas the percentage survival data were analyzed using ANOVA and Tukey's test. Both in vitro growth and ex vitro survival were lowest when the plantlets were grown in the absence of a carbohydrate source and highest (>90\% survival) when supplemented with glucose. According to our findings, the addition of either glucose $\left(30 \mathrm{~g} \mathrm{~L}^{-1}\right)$ or sucrose $\left(30 \mathrm{~g} \mathrm{~L}^{-1}\right)$ is recommended for mass propagation of C. schilleriana.

Key words: in vitro culture; native orchid; glucose; sucrose; acclimatization.
\end{abstract}

\author{
Carboidratos no crescimento de plântulas de \\ Cattleya schilleriana Reichb.f. (Orchidaceae)
}

RESUMO: O objetivo deste estudo foi avaliar a adição de doses de carboidratos em meio de cultura $1 / 2$ MS para a propagação da orquídea Cattleya schilleriana. Plântulas com 120 dias após semeadura foram recultivadas em 12 tratamentos, onde foram investigadas a adição de diferentes doses de frutose, glicose e sacarose $\left(0,15,30\right.$ e $\left.45 \mathrm{~g} \mathrm{~L}^{-1}\right)$. O delineamento utilizado foi inteiramente casualizado com quatro repetições por tratamento. Após 120 dias nos tratamentos, foram mensurados o número de raízes, comprimento da maior raiz, número de folhas, comprimento da maior folha e massa fresca total. Depois as plântulas foram aclimatizadas em casa de vegetação e avaliada a taxa de sobrevivência após 75 dias. Os dados obtidos foram submetidos ao teste de Tukey a 5\% de probabilidade e ajustadas curvas de regressão. A ausência de carboidrato reduziu o crescimento das plântulas entre todas as características avaliadas in vitro e ex vitro. As doses de glicose promoveram maior eficiência para o crescimento in vitro e sobrevivência acima de $90 \%$ após a aclimatização. Assim, a adição de glicose (30g $\left.L^{-1}\right)$ ou sacarose $\left(30 \mathrm{~g} \mathrm{~L}^{-1}\right)$ são recomendadas para a propagação massal de C. schilleriana.

Palavras-chave: cultura in vitro; orquidea nativa; glicose; sacarose; aclimatização.

Cattleya schilleriana Reichb.f.(Orchidaceae) is a bifoliate orchid that is characterized by its cylindrical pseudobulbs and fine, waxy inflorescences (PRIDGEON \& MORRISON, 2006). As a Brazilian endemic, the species inhabits the Atlantic Forest of northeastern (Bahia) and southeastern (Espírito Santo) Brazil and has been intensely collected, owing to its high ornamental potential (BARROS et al., 2010).

Plant tissue culture, which is useful for orchid production, requires the continuous supply of carbohydrates in order to ensure plant growth and survival (PAIVA-NETO \& OTONI, 2003). Therefore, sugars, such as fructose, glucose, and sucrose, are usually added to culture mediums, as organic precursors for the biosynthesis of structural and functional components necessary for plant growth (KANE, 2011).

The role of carbohydrates in the in vitro growth of orchid protocorms (germinated seedlings) have already been examined, in order to elucidate physiological and nutritional requirements of orchids. HEW \& MAH (1989), explored the asymbiotic method for rapid absorption of monosaccharide fructose by differentiated and undifferentiated Dendrobium tissues, and ERNST \& ARDITTI (1990) reported that a broad spectrum of carbohydrates (e.g., glucose, fructose, and oligosaccharides) are suitable for the growth and development of Phalaenopsis. Sucrose was recommended for the propagation of Miltonia flavescens (30 and $45 \mathrm{~g} \mathrm{~L}^{-1}$; BESSON et al., 
2010), Cattleya loddigesii (20g L-1; GALDIANOJÚNIOR et al., 2013), and Phalaenopsis 'Pink'

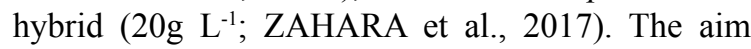
of the present study was to evaluate the effects of carbohydrate supplementation on the propagation of the orchid Cattleya schilleriana.

Seven months after manual pollination, closed mature $C$. schilleriana pods were superficially disinfected, as described by GALDIANO-JÚNIOR et al. (2013). Seeds $(\sim 100 \mathrm{mg})$ were inoculated into $220-\mathrm{mL}$ flasks that contained $40 \mathrm{~mL}$ of autoclaved $\left(121^{\circ} \mathrm{C}\right.$, 1.1atm, $\left.15 \mathrm{~min}\right) 1 / 2 \mathrm{MS}$ culture medium (MURASHIGE \& SKOOG, 1962), 3\% sucrose, and $0.7 \%$ agar (pH 5.7).

During in vitro germination and growth, the seedlings were maintained at $25 \pm 2^{\circ} \mathrm{C}$ and illuminated with white fluorescent light $\left(60 \mu \mathrm{mol} \cdot \mathrm{m}^{-}\right.$ ${ }^{2} \cdot \mathrm{s}^{-1}, 16$-h photoperiod). After $120 \mathrm{~d}$, explants with up to two leaflets that were $1.0 \pm 0.2 \mathrm{~cm}$ in length were assigned to one of the 12 treatments: fructose $(0$, 15,30 , or $\left.45 \mathrm{~g} \mathrm{~L}^{-1}\right)$, glucose $\left(0,15,30\right.$, or $\left.45 \mathrm{~g} \mathrm{~L}^{-1}\right)$, or sucrose $\left(0,15,30\right.$, or $\left.45 \mathrm{~g} \mathrm{~L}^{-1}\right)$ in $1 / 2 \mathrm{MS}$ culture medium. The experimental design was completely randomized, four replicates of 12 seedlings were performed for each treatment group, for a total of 576 seedlings.

When the seedlings were 240-d-old (120 d before treatment +120 -d treatment), in vitro growth was evaluated by measuring the number of roots, length of the largest root, number of leaves, length of the largest leaf, and total fresh mass for each seedling. The seedlings were then acclimatized in a greenhouse that consisted of shade cloth ( $70 \%$ shade) and a plastic cover. Each treatment was conditioned in collective plastic pots, using a completely randomized design, ten seedlings per pot, sphagnum substrate, and daily watering, and percentage survival was evaluated after $75 \mathrm{~d}$.

The in vitro growth data were submitted to regression analysis $(\mathrm{P} \leq 0.05)$, whereas the percentage survival data were analyzed using ANOVA and Tukey's test $(\mathrm{P} \leq 0.05)$ in Sisvar (DEX/UFLA) software, 5.3/1999- 2010 version (FERREIRA, 2010).

Carbohydrate source and concentration significantly influenced the in vitro growth of the C. schilleriana seedlings. After germinating and growing in a sucrose-containing medium for $120 \mathrm{~d}$, the seedlings were able to survive subsequent cultivation without carbohydrates, as previously reported for $C$. walkeriana (DIGNART et al., 2009) and C. loddigesii (GALDIANO-JUNIOR et al., 2013). However, seedlings provided with carbohydrate- supplemented mediums during the experimental period exhibited greater in vitro growth.
Number of roots increased linearly with increasing carbohydrate concentration, irrespective of source (Figure 1A), thereby confirmed previous studies that have suggested that carbohydrate supplementation is effective for promoting in vitro rooting (DIGNART et al., 2009; BESSON et al., 2010; KANE, 2011).

Largest root length also exhibited a positive linear response, when cultivated on medium containing glucose or sucrose (Figure 1B), and the longest roots were produced by seedlings grown on the highest concentration $\left(45 \mathrm{~g} \mathrm{~L}^{-1}\right)$ of glucose. Meanwhile, a quadratic response was observed for fructose supplementation, and maximum growth was estimated to occur at an intermediate fructose concentration (31.18 $\mathrm{g} \mathrm{L}^{-1}$; Figure 1B). Adding fructose to culture medium can cause hyperhydricity and physiological problems, such as the abnormal metabolism of nitrogen or other sugars (BOUZA et al., 1992), which may explain the lower requirement of $C$. schilleriana roots for fructose than for glucose or sucrose.

Number of leaves exhibited a linear response to both fructose and sucrose and a quadratic response to glucose (Figure 1C), and the greatest number of leaves was observed at $25.8 \mathrm{~g} \mathrm{~L}^{-1}$ glucose and at $45 \mathrm{~g} \mathrm{~L}^{-1}$ fructose. Meanwhile, both the length of the largest leaf and fresh mass also exhibited quadratic responses to fructose but exhibited linear responses to both glucose and sucrose (Figure 1D). Furthermore, the greatest leaf length was observed at the highest concentration $\left(45 \mathrm{~g} \mathrm{~L}^{-1}\right)$ of both glucose and sucrose, whereas the maximum fresh weight was estimated to occur at $34.6 \mathrm{~g} \mathrm{~L}^{-1}$ fructose (Figure 1E).

Sucrose has been recommended as the most suitable source of carbon and energy for propagation of in vitro plants (PAIVA-NETO \& OTONI, 2003; KANE, 2011). However, results of the present study indicated that glucose is also acceptable for propagating C. schilleriana, as previously reported by Wotavová-Novotná et al. (2007) and Stewart \& Kane (2010) regarding the orchids Dactylorhiza spp. and Habenaria macroceratitis, respectively. Carbohydrates are a very important component in the nutrient medium of in vitro-cultured orchids, both as sources of energy and as osmotic regulators (JHENG et al., 2006). Sucrose is a disaccharide of glucose and fructose and, despite having a different osmotic potential than glucose, both sucrose and glucose promote the growth of $C$. schilleriana, owing to their essential role in accelerating cell division, mainly by increasing cell expansion and stimulating the accumulation of reserves in young plant organs (PAIVA-NETO \& OTONI, 2003). 


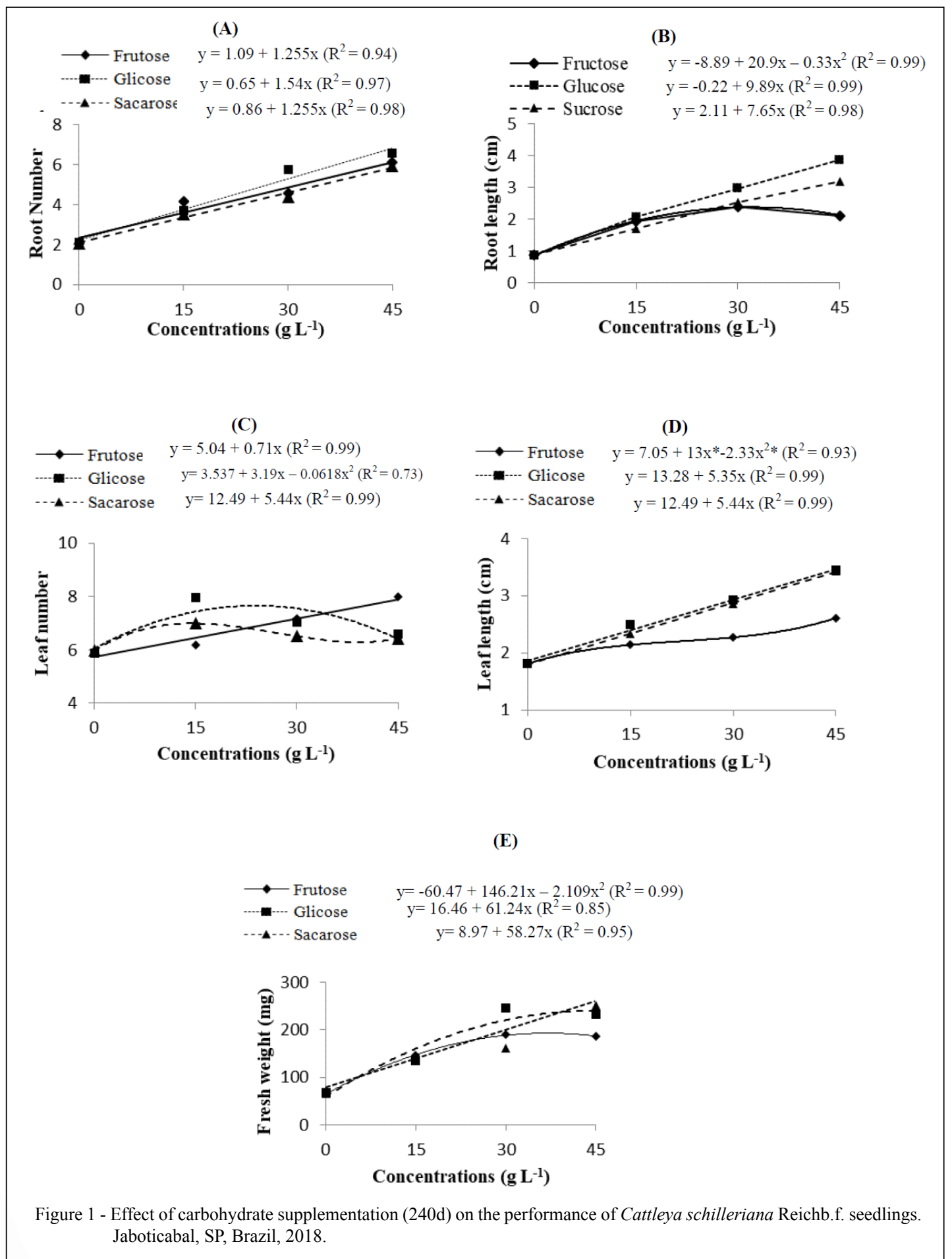

After $75 \mathrm{~d}$ of establishment in a greenhouse, plants grown in the absence of carbohydrates exhibited the lowest survival rate (Figure 2), whereas high levels of glucose supplementation ( 30 and $45 \mathrm{~g} \mathrm{~L}^{-1}$ ) yielded survival rates of 94 and $97 \%$, respectively. Sucrose supplementation $\left(30 \mathrm{~g} \mathrm{~L}^{-1}\right)$ also yielded a relatively high survival rate $(92 \%)$ that was statistically similar to the rates achieved by glucose supplementation. 


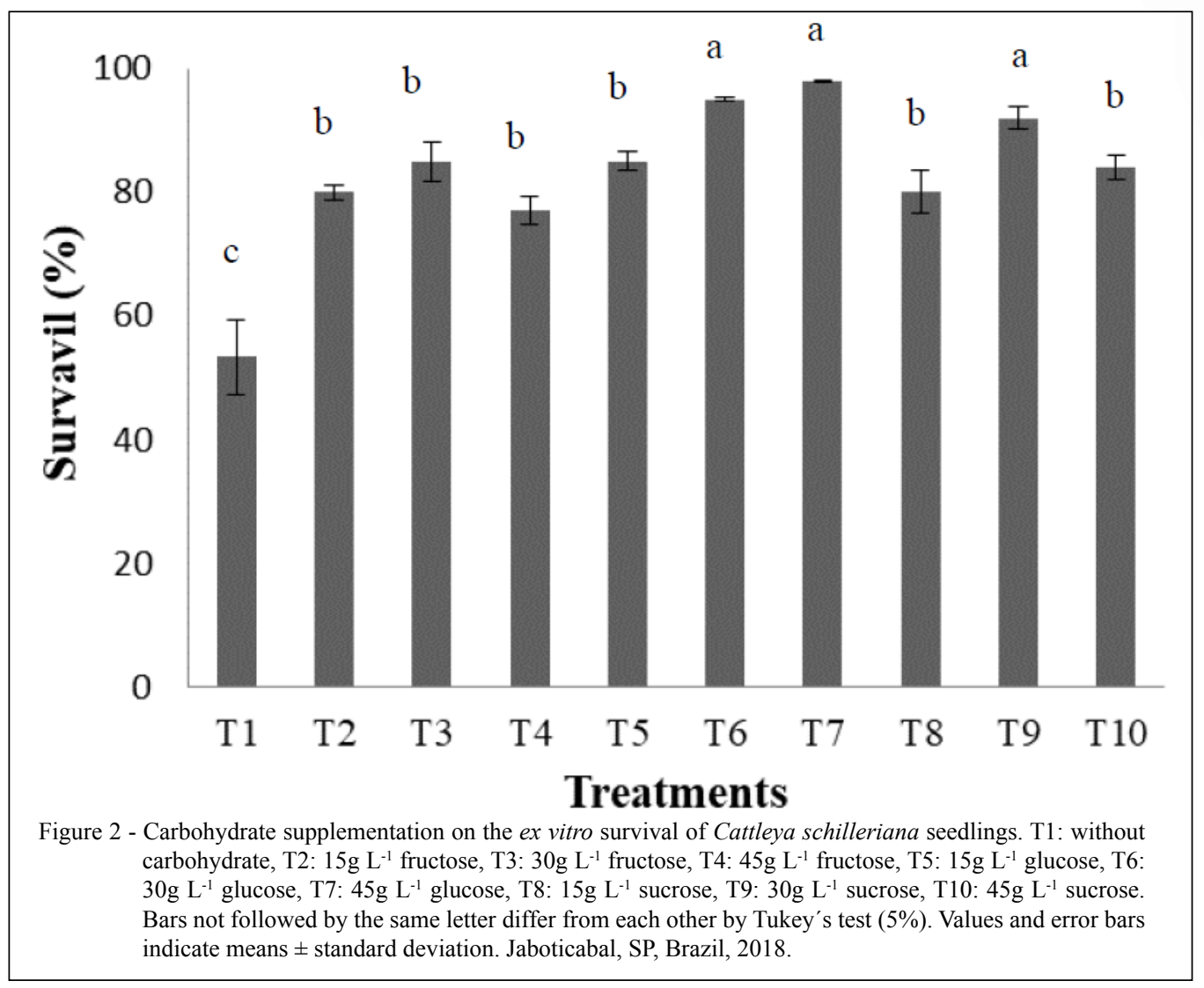

Strong root development, which is crucial to the survival of orchids during acclimatization (DEB \& IMCHEN, 2010) and is associated with greater seedling growth, was observed in response to both glucose $\left(30\right.$ and $\left.45 \mathrm{~g} \mathrm{~L}^{-1}\right)$ and sucrose $\left(30 \mathrm{~g} \mathrm{~L}^{-1}\right)$ supplementation in vitro and may have contributed to the high rates of survival observed ex vitro. It is worth noting that using the lower effective dose of glucose $\left(30 \mathrm{~g} \mathrm{~L}^{-1}\right)$ could be more cost-effective during the in vitro propagation phase and is, therefore, more efficient. Addition of carbohydrates alters the in vitro growth and survival of $C$. schilleriana under greenhouse conditions, and intermediate levels of glucose or sucrose supplementation $\left(30 \mathrm{~g} \mathrm{~L}^{-1}\right)$ are recommended for the mass propagation of $C$. schilleriana seedlings.

\section{ACKNOWLEDGEMENTS}

The authors are grateful to Conselho Nacional de Desenvolvimento Científico e Tecnológico (CNPq) for felloship.

\section{CONFLICTS OF INTEREST}

The authors declare no conflict of interest. The founding sponsors had no role in the design of the study; in the collection, analyses, or interpretation of data; in the writing of the manuscript, and in the decision to publish the results.

\section{REFERENCES}

BARROS, F. de et al. Orchidaceae. In: Lista de Espécies da Flora do Brasil. Jardim Botânico do Rio de Janeiro. 2010. Available from: $<$ http://floradobrasil.jbrj.gov.br/reflora/floradobrasil/FB11343>. Accessed: Jun. 10, 2018.

BESSON, J.C.F. et al. Fontes e concentrações de carboidratos no crescimento vegetativo e no enraizamento in vitro de Miltonia flavescens Lindl. Revista Brasileira de Biociências, v.8, n.1, p.9-13, 2010.

BOUZA, L. et al. Y. In vitro propagation of Prunus tenella Batsch. cv. 'Firehill': control of vitrification increase of the multiplication rate and growth by chilling. Scientia Horticulture, v.52, p.143-155, 1992.

DEB, C.R.; IMCHEN, T. An efficient hardening technique of tissue cultured raised plants. Biotechnology, v.9, n.1, p.79-83, 2010. 
DIGNART, S.L. et al. Luz natural e concentrações de sacarose no cultivo in vitro de Cattleya walkeriana. Ciência e Agrotecnologia, v.33, n.3, p.780-787, 2009.

ERNST, R.; ARDITTI, J. Carbohydrate physiology of orchid seedlings III: Hydrolysis of maltooligosaccharides by Phalaenopsis (Orchidaceae) seedlings. American Journal of Botany, v.77, p.188-195, 1990.

FERREIRA, D. F. Programa computacional Sisvar - UFLA, versão $5.3,2010$.

GALDIANO-JÚNIOR, R. F. et al. Concentrações de sacarose no desenvolvimento in vitro e na aclimatização de Cattleya loddigesii Lindley. Semina, v. 34, n. 2, p. 583-592, 2013.

HEW, C.S. \& MAH, T.C. Sugar uptake and invertase activity in Dendrobium tissues. New Phytologist, v.111, p.167-171, 1989.

JHENG, F. Y. et al. Enhancement of growth and regeneration efficiency from embryogenic callus cultures of Oncidium 'Gower Ramsey' by adjusting carbohydrates sources. Plant Science, v. 170 , p. 1133-1140, 2006.

KANE, M.E. Propagation by shoot culture. In: TRIGIANO, R.N. \& GRAY, D.J. (Eds) Plant Tissue Culture, Development and Biotechnology. Boca Raton: CRC Press, p.181-192, 2011.
MURASHIGE, T. \& SKOOG, F. A revised medium for a rapid growth and biossays with tabacco tissue cultures. Physiologia Plantarum, v.15, p.473-497, 1962.

PAIVA-NETO, V.B. \& OTONI, W.C. Carbon sources and their osmotic potential in plant tissue culture: does it matter? Science Horticulture, v.97, p.193-202, 2003.

PRIDGEON, A. \& MORRISON, A. The illustrated encyclopedia of orchids: over 1100 species illustrated and identified. Oregon: Timber Press, 2006. p. 56.

STEWART, S.C. \& KANE, M.E. Effects of carbohydrate source on the in vitro asymbiotic seed germination of the terrestrial orchid Habenaria macroceratitis. Journal of Plant Nutrition, v.33, p.1155-1165, 2010.

WOTAVOVÁ-NOVOTNÁ, K. et al. Effects of sugars and growth regulators on in vitro growth of Dactylorhiza species. Biologia Plantarum, v.51, n.1, p.198-200, 2007. doi: 10.1007/s10535-0070040-x.

ZAHARA, M. et al. The effects of different media, sucrose concentrations and natural additives on plantlet growth of Phalaenopsis hybrid 'Pink'. Brazilian Archives of Biology and Technology, v.60: e17160149, 2017. doi: 10.1590/1678-43242017160149. 